Determinants of Narrative Risk Disclosures in UK Interim Reports

\author{
Hany Elzahar \\ Stirling University
}

and

Khaled Hussainey*

Stirling University

* We would like to thank Professor Michael Powers (the Editor) and an anonymous referee for their useful comments and suggestions. We thank our colleague Alaa Zalata for his helpful comments. Correspondence should be address to Dr. Khaled Hussainey, Accounting \& Finance Division, Stirling Management School, University of Stirling, Stirling, FK9 4LA, Scotland, UK. Email: Khaled.Hussainey@stir.ac.uk. 


\title{
Determinants of Narrative Risk Disclosures in UK Interim Reports
}

\begin{abstract}
Purpose - This paper contributes to the existing disclosure literature by examining the determinants of narrative risk information in the interim reports for a sample of UK non financial companies.
\end{abstract}

Methodology - This study uses the manual content analysis to measure the level of risk information in interim report narrative sections prepared by 72 UK companies. It also uses the OLS regression analysis to examine the impact of firm-specific characteristics and corporate governance mechanisms on narrative risk disclosures.

Findings - The empirical analysis shows that large firms are more likely to disclose more risk information in the narrative sections of interim reports. In addition, the analysis shows that industry activity type is positively associated with levels of narrative risk disclosure in interim reports. Finally, the analysis shows statistically insignificant impact of other firmspecific characteristics (liquidity, gearing, profitability and cross-listing) and corporate governance mechanisms on narrative risk disclosure.

Practical implications - The study's findings have practical implications. It informs investors about the characteristics of UK companies that disclose risk information in their interim reports. For example, the findings shows that narrative risk disclosures is affected by firm size and industry type rather than firms' risk levels (e.g. financing risk measured by the gearing ratio or liquidity risk measured by lower liquidity ratios). Practical implications for managers from these findings are that, in order to keep investors satisfied, companies with high levels of financing and liquidity risks should look at investors' demands for risk disclosure. This will help investors when making their investment decisions.

Originality/value - The determinants of narrative risk disclosure in interim reports has not been explored so clearly in prior research and therefore this study is the first of its kind to examine this research issue for a sample of UK companies.

Keywords - Narrative risk disclosure, Interim reports, Content analysis, UK.

Paper type - Research paper. 


\section{Introduction}

The changes in business environment make firms more relying on financial instruments and international transactions, which raise the importance of corporate risk disclosure (CRD), especially in non-financial firms (Dobler, 2008). Companies try to satisfy accounting information users' needs by disclosing more information about different risks being faced and the sustainability of their operations. Such information helps the users to assess the present and the future risk, which is essential to optimise their revenues, by holding well diversified portfolios (Abraham and Cox, 2007). Solomon et al. (2000) showed a strong demand for increased CRD from institutional investors to improve portfolio-investment decisions. Risk disclosure helps in investors' investment decisions-making process by evaluating the information disclosed by a firm in order to establish levels of various risks it faces, then; their decision will be taken based on expected return and risk considerations (Cabedo and Tirado, 2004). Moreover, CRD will lead to a better risk management, as well as improvement of accountability for stewardship, investor protection, and the usefulness of financial reporting (ICAEW, 1997). This would help financial reports' users to identify potential managerial problems (or opportunities) and assess management's effectiveness in dealing with these issues (Lajili and Zéghal, 2005). On the other hand, companies also benefit from risk disclosure by reducing the possibility of financial failure (Beretta and Bozzolan, 2004); it also can make a decline in the cost of external finance (Linsley and Shrives, 2006).

Despite of recent increase in risk research, prior CRD studies focused on CRD determinants in the annual reports (Abraham and Cox, 2007; Beretta and Bozzolan, 2004; Hassan, 2009; Lajili and Zéghal, 2005; Linsley and Shrives, 2000, 2005 and 2006; Marshall and Weetman, 2002 and 2007; Rajab and Handley-Schachler, 2009; Elshandidy et al, 2011; Vandemaele et al., 2009) and/or for companies listed in regulated risk reporting environments (Hodder and McAnally, 2001; Jorgensen and Kirschenheiter, 2003 and 2007; Jorion; 2002; Linsmeier et al, 2002; Rajgopal, 1999). Our paper aims at investigating the factors affecting CRD in UK interim reports. To the best of our knowledge; there is no study that provides empirical evidence concerning the determinants of CRD level in these reports. It would be interesting to investigate those determinants in such setting for two reasons. First, most mandatory rules are concerning disclosure of financial risks and internal control assessment. The absence of an integrated framework for CRD, beside the non-mandatory approach of corporate governance (CG) provisions in the UK, affects CRD level to be basically determined by management decisions. Hence, it is important to explore the possible drivers to extend or 
reduce CRD level. Second, the interim report is considered as an effective mechanism to improve mangers voluntary disclosure decisions (Healy and Palepu, 2001). The timeliness plays an important role to make interim reports more informative. Investors and analysts usually rely on these reports either in making their assessments, or in updating their prior expectations (Cornell and Landsman, 1989; Landsman and Maydew, 2002). In the UK, a half-yearly interim report is a requirement of London Stock Exchange. In addition, the Accounting Standard Board (ASB) provides voluntary best practice guidance for companies in its statement on interim reports (ASB, 1997). Moreover, the International Accounting Standards (IAS 34) was issued in 1998 to improve interim reports disclosure (IASB, 1998). However, disclosure requirements according to those regulations are generally less than those required in the annual reports. For the interests of timeliness and cost considerations, companies are allowed to not include all of the disclosures required by the full set of IFRSs (IAS 34, par.18). Therefore, not all of the supplementary notes in the annual report are required for interim reporting purposes. Furthermore, companies can select to prepare condensed interim reports rather than complete ones. Based on this option, more chances are given to voluntarily disclose on risk information. That interesting environment motives us to examine CRD determinants in the interim reports of UK companies. We draw on agency and signalling theories to examine the determinants of narrative risk disclosures in these reports

The remainder of our paper is organised as follows. Section 2 reviews relevant literature and develops our hypotheses. Section 3 discusses the research methodology. Section 4 presents the empirical analysis. Section 5 concludes.

\section{Literature review and hypotheses development}

Prior research argued that a joint consideration of disclosure theories should be of great help in explaining a particular phenomenon by providing richer insights into the understanding of corporate disclosure practices, thus disclosure theories should be considered as complementary rather than competing (Carpenter and Feroz, 1992). Similarly, Morris (1987) argues that there is a consistency between both of agency theory and signalling theory. He suggests that a combination between them could get a better prediction of accounting choices. Therefore, agency and signalling theories are used together to explain the determinants of CRD. To reduce agency problems; managers have to present relevant information to prove their acting in the interests of the shareholders and debt 
holders (Healy and Palepu, 2001). The provision of reliable information about risk by the management (the insider who has risk information) to the investors and debtholders (the outsiders who usually do not have that information) will reduce information asymmetry problem. Whereas, signalling theory explains managers' incentives to disclose more information in the accounting reports (e.g. Hughes, 1986; Haniffa and Cooke, 2002). Based on this theory, managers disclose adequate information in the financial reports in order to convey specific signals to current and potential users. Hughes (1986) argued that this kind of communication is credible to the investors because managers with fraudulent signals will be penalised. In the present paper, we use both agency and signalling theories to identify the potential drivers of risk information in interim reports. In developing our research hypotheses, we look at the potential association between firm characteristics, corporate governance mechanisms and risk reporting.

\subsection{Firm characteristics and CRD}

Several empirical studies provide evidence that various other firm characteristics affect corporate disclosure levels (see Table 1). This group of characteristics contains six variables namely: sector type, size, cross listing, profitability, liquidity and gearing,

\section{Insert Table 1 here}

Sector type: Prior research investigated the relationship between disclosure levels and the sector type; however, the results are mixed. For example, some studies found an insignificant relationship between the two variables (Wallace et al., 1994; Alfieri and Husainy, 2007). Others found a relationship between sector type and corporate disclosure (Cooke 1992; Mangena and Pike, 2005). In risk reporting studies, Beretta and Bozzolan (2004) and Rajab and Handley-Schechter (2009) found that risk reporting differs among different industry sectors. Signalling theory suggests that firms in the same industry sector are more likely to adopt the same level of disclosure (Aly et al., 2010). If a company within an industry fails to follow the same disclosure practices as others in the same industry, then it may be interpreted as a signal of hiding bad news (Craven and Marston, 1999). We predict that CRD in interim reports would be affected by different types of businesses. Different industries would be influenced by different and unique constraints in their business environment. Consequently, risks types and levels will differ among sectors according to complexity in value creation activities and the extent of risk exposure in each sector environment. Based on signalling theory and prior risk reporting studies, we formulate our first hypothesis as follows: 
H1. The level of CRD in interim reports differs among industrial and service sectors.

Firm size: According to agency theory, larger firms need to disclose more information to different user groups which lead to a decline in agency costs and to reduce information asymmetries (Watts and Zimmerman, 1983, Inchausti, 1997). Meanwhile, those companies have enough resources to afford the cost of additional disclosure production. Prior disclosure studies found a positive relationship exists between a firm size and its level of disclosures (Hossain et al., 1995; Mangena and Pike, 2005; Hassan et al., 2006).

In prior CRD studies, the association between firm size and risk reporting is mixed. For example, while Beretta and Bozzolan (2004), Elshadidy et al (2011) and Vandemele et al. (2009) found a positive association between firm size and levels of CRD, Hassan, (2009) and Rajab and Handley-Schechter (2009) found insignificant association between the two variables. We anticipate that large firms rely on external finance; hence, they have incentives to disclose more risk information to send a good signal to investors and creditors about their ability to manage risk. In addition, large firms have sufficient resources to cover the cost of additional risk disclosures. Therefore, based on agency theory, we formulate the second hypothesis as follows:

H2. Large firms are more likely to disclose more risk information in their interim reports than small firms.

Cross listing: Taylor et al. (2010) found that overseas stock exchange listing is negatively associated with financial risk management disclosure patterns. This result is inconsistent with prior literature that found a positive association between disclosure and cross-listing (Mangena and Pike, 2005; Rajab and Handley-Schechter, 2009). Cross-listing gives firms many chances to make access to many alternative sources of finance. Even if, there is a different regulatory frameworks which require additional risk disclosures, directors will have incentives to provide more risk information in the financial reports. In order to make their securities more attractive, directors need to send good signals about different risks, risk management activities, and operations' sustainability. Prior risk reporting studies shows a positive association between cross-listing and levels of disclosure (Rajab and HandleySchechter, 2009). Based on signalling theory and prior risk reporting studies, we formulate the third hypothesis as follows:

H3. CRD levels in interim reports for UK firms with a US-dual listing are higher than those without a US-dual listing. 
Profitability: Ahmed and Courtis (1999) showed that prior studies results provide mixed evidence on the association between firm's profitability and level of corporate disclosure. Regarding risk disclosure studies, Vandemele and et al. (2009) reported a negative relationship between profitability and risk disclosure level, while Elshandidy et al (2011) report a positive association. Nonetheless agency theory expects that managers of companies with high profitability would tend to provide more risk information in the interim reports, in order to justify their present performance to the shareholders. Based on agency theory, we formulate our fourth hypothesis as follows:

H4.CRD levels in interim reports for companies with high profitability figures are greater than those companies with low profitability figures.

Liquidity: According to signalling theory, companies' managers will disclose more information if their liquidity ratios are high, to distinguish their skills in managing liquidity risks comparing with other managers in companies with lower liquidity ratios. Although prior research on the association between liquidity and corporate disclosure is limited, the results are mixed. For example, Wallace et al. (1994) found a negative association suggesting that companies with lower liquidity provide more information in their annual reports. On the other hand, Mangena and Pike (2005) found no statistically significant association between disclosure levels in interim reports and liquidity. In risk disclosure literature, the results are also consistent with signalling theory. For example Marshall and Weetman (2007) and Elshandidy et al (2011) found that high-liquidity firms provide more risk information to send positive signals to investors. Based on signalling theory and relevant risk studies, we formulate our fifth hypothesis as follows:

H5. CRD levels in interim reports for companies with high liquidity ratios are greater than those companies with low liquidity ratios.

Gearing: Based on agency theory, agency costs are higher in highly leveraged firms. To reduce these costs; companies need to disclose more information to satisfy the need of creditors (Jensen and Meckling, 1976). Moreover, managers tend to provide more risk management information in order to send a good signal to debtholders regarding the corporate ability to meet its obligations. Empirical evidence on the association between the gearing and CRD is mixed. While, Deumes and Knechel (2008), Elshandidy et al (2011), Hassan (2009), Marshall and Weetman (2007) and Taylor et al. (2010) found a positive relationship between the two variables, Abraham and Cox (2007), Linsley and Shrives (2006) 
and Rajab and Handley-Schachler (2009) found insignificant association between the two variables. Based on agency theory, we formulate our sixth hypothesis as follows:

H6. Highly gearing companies are more likely to disclose more risk information in their interim reports compared with low gearing companies.

\subsection{Corporate Governance and CRD}

For the corporate governance mechanisms, Taylor et al. (2010) argued that firms with strong corporate governance structure are more effective in financial risk management; that is reflected as enhanced financial risk management disclosures. To examine the association between corporate governance $(\mathrm{CG})$ mechanisms and CRD in interim reports; we use the following variables institutional ownership, board size, role duality, board independence, and audit committee (AC) size. Table 2 summarises the expected signs between CRD reporting and the various CG explanatory factors used in this study.

\section{Insert Table 2 here}

Institutional ownership: Agency theory predicts that ownership structure affects the level of monitoring in the firm; therefore, it has an impact on the level of corporate voluntary disclosure (Eng and Mak, 2003). The relationship between institutional ownership and disclosure has been examined in prior studies, the empirical evidence, however, is mixed. While Schadewitz and Blevins (1998) found a negative association between institutional ownership and disclosure level in interim disclosures, Mangena and Pike (2005) found a positive association between the two variables. Eng and Mak (2003), on the other hand, found insignificant relationship between the two variables. Companies with a concentrated ownership structure do not have to disseminate more risk information, because the main shareholders can easily obtain it, as they usually have access to that information. Based on agency theory, we formulate our seventh hypothesis as follows:

H7: There is a negative relationship between CRD levels in interim reports and institutional ownership.

Board size: Board of directors plays an important role in the corporate governance of publicly listed companies. However, It is argued that UK boards play a much weaker monitoring role as a result of CG soft regulation in the UK which allow firms to choose the board size most appropriate for their own needs (Guest, 2008). Agency theory predicts that larger boards incorporate a variety of expertise which results in more effectiveness in boards' monitoring role (e.g. Singh et al., 2004). Based on that argument; it is predicted that a 
positive association between board size and CRD, as larger boards' members would have more incentives to signal their risk management performance to the firm shareholders. Moreover, the large board will help in increasing the number of members who have financial and accounting background, which could affect mangers voluntary disclosure decisions and extend CRD level. Based on agency theory, we formulate our eighth hypothesis as follows:

H8: There is positive association between board size and CRD levels in the interim reports.

Role duality: Role duality occurs if the chief executive officer (CEO) holds the chairman position in the same time. Concentration of decision-making power resulting from role duality could impair the board's governance role regarding disclosure policies (Li et al., 2008). The results of previous studies that examined the relationship between role duality and disclosure were mixed. For instance, some studies reported a negative relationship between role duality and corporate voluntary disclosure (Forker, 1992; Haniffa and Cooke, 2002). Other studies found insignificant association between CEO duality and voluntary disclosure in general (Ho and Wong, 2001) and risk reporting in particular (Vandemele and et al., 2009). Based on these mixed arguments, we formulate our ninth hypothesis as follows:

H9. There is a relationship between role duality and CRD levels in interim reports.

Board composition: Based on agency theory, the monitoring role of the board is to ensure that corporate management pursues shareholder interests. Outsider directors are expected to provide independent advices to executive directors. The boards with a higher proportion of non-executive directors are expected to be more effective in performing monitoring role; and thereby affect positively on accounting reporting quality; as they aim to signal their competence to other potential employers (Fama and Jensen, 1983). Prior studies on the association between board composition and disclosure are mixed. Some studies found insignificant relationship between the two variables (Ho and Wong, 2001; Haniffa and Cooke, 2002, Vandemele and et al., 2009), while others found a positive relationship (Forker, 1992; Cheng and Courtenay, 2006, Abraham and Cox, 2007). Based on agency theory, we formulate out tenth hypothesis as follows:

H10. There is a positive relationship between the proportion of non-executive directors in the board and the levels of CRD.

AC size: The Combined Code (2010) recommends that the audit committee (AC) should involve at least three, or in the case of smaller companies two, independent non-executive directors. Smith Committee Report (2003), states that AC should review the company's 
internal financial control system as well as risk management systems. Mangena and Pike (2005) suggested that larger audit committees give rise to more effective monitoring, since it is more likely to involve the necessary of expertise and views to do that. Prior research on the association between AC size and disclosure offered mixed results. While Mangena and Pike (2005) found insignificant association between the two variables, Felo et al. (2003) found a positive relationship. Based on these mixed arguments, we formulate our eleventh hypothesis as follows:

\section{H11. There is a relationship between AC size and CRD levels in interim reports}

\section{Methodology}

\subsection{Sample and data}

Our sample consists of the interim reports for the FTSE 100 UK non-financial firms. Following Beretta and Bozzolan (2004), Linsley and Shrives (2006), and Abraham and Cox (2007), financial companies (e.g. banks and insurance companies) were removed from the sample, since they have specific characteristics together with different framework for disclosure practices according to their regulations. We choose interim reports published between $1^{\text {st }}$ June 2009 and $31^{\text {st }}$ May 2010. Interim reports are collected from companies' homepages. Companies that only upload presentations for their interim results are excluded. We also exclude companies with missing accounting and corporate governance information. This gives us a final sample of $72 \mathrm{UK}$ companies.

\subsection{Regression model}

We use the following OLS regression model to examine the relationship between CRD in the interim reports and both of firm characteristics and CG mechanisms:

$$
\begin{aligned}
\text { CRD }= & \beta_{0}+\beta_{1} \text { Industry }+\beta_{2} \text { Size }+\beta_{3} \text { Prof }+\beta_{4} \text { Gear }+\beta_{5} \text { Liq }+\beta_{6} \text { Croslist }+\beta_{7} \text { Inst }+ \\
& \beta_{8} \text { Dual }+\beta_{9} \text { Bsize }+\beta_{10} \text { Nonexc }+\beta_{11} \text { AC size }+\varepsilon
\end{aligned}
$$

where:

CRD $=$ Risk disclosure score;

$\beta_{0}=$ the intercept;

$\beta_{1} \ldots \beta_{11}=$ Regression coefficients

$\varepsilon \quad=$ Error term.

\subsubsection{Dependent variable: Risk Disclosure Score}

Following prior studies (e.g., Linsley and Shrives, 2006; Rajab and Handley-Schachler, 2009), content analysis has been employed to measure the level of risk disclosure in the interim reports. We use the number of risk-related sentences as a measure of risk disclosure 
levels. Following Linsley and Shrives (2006), a broad definition of risk is adopted to identify risk disclosures. Therefore, sentences are to be coded as risk disclosures if the reader is informed of any opportunity or prospect, or of any hazard, danger, harm, threat or exposure, that has already impacted lor may impact upon the company, as well as the management of any such opportunity, prospect, hazard, harm, threat or exposure. However, disclosures should be explicitly stated and they can not be implied, so any disclosure is not recorded as a risk disclosure when it is too vague. Whereas, any disclosure that is repeated is considered as a risk disclosure sentence each time it is mentioned. Furthermore, both authors coded a sample of interim reports independently to ensure consistency in applying those rules, no disagreement between the authors exist. We calculate an aggregated score for risk disclosure for each firm by counting the number of risk-related sentences in the UK interim reports.

\subsubsection{Independent variables}

To examine the determinants of $\mathrm{CRD}$, we collect firm characteristics and corporate governance information from different sources. Table 1 summarises the measurement and definition of those variables.

Insert Table 3 here

\subsection{Descriptive analysis}

Table 2 presents the descriptive statistics. Panel A reports the descriptive analysis for the continuous variables. Panel A shows a number of observations. First, it shows that the mean total risk disclosure is 28 sentences. Second, it also shows that there is a large variation in risk reporting between firms with a minimum of 5 sentences, a maximum of 110 sentences. Panel A also shows that the sample represents the largest UK firms with a mean of total assets of 18136.2 million. These firms look financially healthy as the mean liquidity ratio is 1.39. Majority of firms in our sample are making profit with a mean profitability ratio of $22.9 \%$. The panel also shows that the firms in our sample are highly leveraged with a mean of a gearing ratio of $167.9 \%$. Mean institutions' shareholding is $70.9 \%$, while mean board size is 11 directors, and more than $68.14 \%$ of the board in the sample consists of non-executive directors. Finally, the panel shows that the size of the audit committee ranges from 2 to 7 directors with a mean of 4 . Panel B shows that $69.44 \%$ of the sample represents industrial firms, and $26.39 \%$ of the companies are listed in the US. It also shows that the majority of the sample firms (95.44\%) make a distinction between the chairman and the CEO positions. 
Insert Table 4 here

\section{Empirical Analysis:}

We use OLS regression analysis to examine the determinants of total risk disclosure ${ }^{1}$. Table 5 shows that industry and firm size are significantly associated with the total risk disclosure in UK interim reports. The coefficients on the industry variable are positive and statistically significant at the 5\% level. This provides a substantial support for the hypothesis 1 which predicts that CRD in interim reports would be affected by different types of businesses. This result is consistent with prior CRD studies in the annual reports (e.g. Abraham and Cox, 2007; Rajab and Handley-Schechter, 2009). Our findings show that industrial companies report more risk information than service companies. This significant impact might reflect greater business threats and uncertainties that faced by industrial companies during the financial crisis. Table 5 also shows that the relation between total CRD level and firm size is positive and statistically significant at the $1 \%$ level. This leads us to accept hypothesis 2 . This finding is consistent with prior research (i.e. Linsley and Shrives, 2006; Vandemele and et al., 2009; Taylor et al., 2010). The finding is also in line with agency and signalling theories indicating that larger firms tend to disclose more risk information to make a decline in agency costs and to reduce information asymmetries.

On the other hand, Table 5 shows that the association between total risk disclosure and other firm characteristics and corporate governance variables is insignificant. Therefore, we reject hypotheses 3-11.

\section{Insert Table 5 here}

\section{Conclusion}

Our paper contributed to existing risk reporting literature by being the first to examine the determinants of CRD in interim reports using UK settings. We test the degree to which firmspecific characteristics and corporate governance mechanisms affect firms' decision to voluntarily report risk information in their interim reports. We used both qualitative and quantitative methods to test our research hypotheses. We used the manual content analysis approach to count the number of risk-related sentences in a sample of 71 the interim reports.

\footnotetext{
${ }^{1}$ We check for the multicollinearity problem by looking at the correlation between the independent variables. Our correlation analysis (not tabulated) shows that the correlations between the independent variables are too low.
} 
OLS regression analysis is also used for the empirical analysis. Our dependent variable was the total number of risk-related sentences, while the independent variables were a set of firmspecific characteristics and a set of corporate governance mechanisms.

Our empirical analysis shows that company size is positively associated with the total CRD level. This finding is consistent with prior risk reporting studies (Abraham and Cox, 2007; Beretta and Bozzolan, 2004; Elshandidy et al, 2011; Linsley and Shrives, 2006; Rajab and Handley-Schechter, 2009; Vandemele et al., 2009). We also find that type of business is positively associated with the total CRD level. Our results are also consistent with both agency and signalling theories. Whereas the other firm characteristics variables (profitability, liquidity, gearing and cross listing) are found to have an insignificant relationship with the level of total CRD in interim reports. In addition, the results don't support that $\mathrm{CG}$ attributes (institutional ownership, role duality, board size, board composition and audit committee size) have a significant effect on CRD in interim reports.

Our study suffers from a number of limitations. First, it calculates risk-related disclosure scores by simply adding up the number of risk-related sentences. This approach ignores the fact that the usefulness of disclosures can vary from sentence to sentence. It also ignores the underlying tone of disclosures (good news versus bad news). Second the sample size is rather small (due to the use of the manual content analysis which requires a considerable time and effort). Therefore, the findings might not be generalised.

The present study suggests a number of other avenues for future research. We explore the main drivers of risk reporting in interim reports in the UK. It would be interesting to reexamine the determinants of risk reporting in interim reports across countries. Future research can use computer software packages to measure risk-related disclosures for a large number of firms with minimal time and effort. Additional research could be also undertaken to examine the economic consequences of risk reporting in interim reports (i.e. the effect of risk reporting in interim reports on prices leading earnings, cost of capital, analyst following and the characteristics of analysts' forecasts). 


\section{References}

AbdelFattah, T., Dixon, R. and Woodhead, A. (2008), "Corporate governance and voluntary disclosure in emerging capital markets: Evidence from Egypt', Working paper, Durham University, UK.

Abraham, S. and Cox, P, (2007), "Analysing the determinants of narrative risk information in UK FTSE 100 annual reports”, The British Accounting Review, Vol. 39, No. 3, pp. 227-248.

Ahmed, K. and Courtis, K. (1999), "Associations between corporate characteristics and disclosure levels in annual reports: a meta-analysis", The British Accounting Review, Vol. 31, No. 1, pp. 35-61.

Aly, D., Simon, J. and Hussainy, K. (2010), "Determinants of corporate internet reporting: evidence from Egypt", Managerial Auditing Journal, Vol. 25, No. 2, pp. 182-202.

Beretta, S., and Bozzolan, S. (2004), "A framework for the analysis of firm risk communication", The International Journal of Accounting, Vol. 39, No. 3, pp. 265-288.

Cabedo, J. and Tirado, J. (2004), "The disclosure of risk in financial statements", Accounting Forum, Vol. 28, No.2, pp. 181-200.

Carpenter, V. and Feroz, E. (1992), “GAAP as a symbol of legitimacy: New York state's decision to adopt generally accepted accounting principles', Accounting, Organizations and Society, Vol.17, No.7, pp. 613-643.

Cheng, E. and Courtenay, S. (2006), "Board composition, regulatory regime and voluntary disclosure", The International Journal of Accounting, Vol. 41, No. 3, pp. 262-289.

Cooke, T. (1992), "The impact of size, stock market listing and industry type on disclosure in the annual reports of Japanese listed corporations", Accounting \& Business Research, Vol. 22, No. 87, pp. 229-237.

Cornell, B. and Landsman, W. (1989), "Security price response to quarterly earnings announcements and analysts' forecast revisions", Accounting Review, Vol. 64, No. 4, pp. 680-692.

Craven, B. and Marston, C. (1999), "Financial reporting on the internet by leading UK companies", The European Accounting Review, Vol. 8, No. 2, pp. 321-33.

Deumes, R. and Knechel, W. (2008), "Economic incentives for voluntary reporting on internal risk management and control systems", Auditing: A Journal of Practice \& Theory, Vol. 27, No. 1, pp. 35-66.

Dobler, M. (2008), "Incentives for risk reporting: a discretionary disclosure and cheap talk approach", The International Journal of Accounting, Vol. 43, No. 1, pp. 184-206.

Elshandidy, T., Fraser, I and Hussainey, K. (2011), "Aggregated, voluntary, and mandatory risk disclosures incentives: evidence from UK FTSE all share”, Working paper, Stirling University, UK. 
Eng, L. and Mak, Y. (2003), "Corporate governance and voluntary disclosure", Journal of Accounting and Public Policy, Vol. 22, No. 4, pp. 325-345.

Fama, E, and Jensen, M. (1983), "Separation of ownership and control”, Journal of Law \& Economics, Vol. 26, No. 4, pp. 9-15.

Felo, A., Krishnamurthy, S. and Solieri, S. (2003), "Audit committee characteristics and the perceived quality of financial reporting: an empirical analysis", Available at: http://papers.ssrn.com/sol3/papers.cfm?abstract_id=401240 (Accessed 4 August 2010).

Forker, J. (1992), "Corporate governance and disclosure quality", Accounting and Business Research, Vol. 22, No. 86, pp. 111-124.

Guest, P. (2008), "The determinants of board size and composition: evidence from the UK", Journal of Corporate Finance, Vol. 14, pp. 51-72.

Haniffa, R. and Cooke, T. (2002), "Culture, corporate governance and disclosure in Malaysian corporations", ABACUS, Vol. 38, No. 3, pp. 317-349.

Hassan, M. (2009), "UAE corporations-specific characteristics and level of risk disclosure", Managerial Auditing Journal, Vol. 24, No. 7, pp. 668-687.

Hassan, O., Giorgioni, G. and Romilly, P. (2006), "The extent of financial disclosure and its determinants in an emerging capital market: the case of Egypt", International Journal of Accounting, Auditing and Performance Evaluation, Vol. 3, No. 1, pp. 41-67.

Healy, P. and Palepu, K. (2001), "Information asymmetry, corporate disclosure, and the capital markets: a review of the empirical disclosure literature", Journal of Accounting and Economics, Vol. 31, No. 1, pp. 405-440.

Ho, S. and Wong. (2001), "A study of the relationship between corporate governance structures and the extent of voluntary disclosure", Journal of International Accounting, Auditing \& Taxation, Vol. 10, No. 1, pp. 139-156.

Hodder, L., McAnally, M. (2001), “SEC market-risk disclosures: enhancing comparability” Financial Analysts Journal, Vol.57, No.2, pp.24-34.

Hossain, M., Perera, B. and Rahman, R. (1995), "Voluntary disclosure in the annual reports of New Zealand companies", Journal of International Financial Management and Accounting, Vol. 6, pp. 69-87.

Hughes, P. (1986), "Signalling by direct disclosure under asymmetric information", Journal of Accounting and Economics, Vol. 8, No. 2, pp. 119-142.

Hussainey, K., and Al-Najjar, B. (2011), “Future-oriented narrative reporting: determinants and use', Journal of Applied Accounting Research, Vol. 12, No. 2, pp. 123-138.

Inchausti, B. (1997) "The influence of company characteristics and accounting regulation on information disclosed by Spanish firms", The European Accounting Review, Vol. 6, No. 1, 45-68. 
Institute of Chartered Accountants in England and Wales (1997), "Financial Reporting of Risk: Proposals for a Statement of Business Risk', London: ICAEW.

Jensen M. and Meckling, W. (1976), "Theory of the firm: managerial behaviour, agency costs and ownership structure', Journal of Financial Economics, Vol. 3, pp. 305-360.

Jorgensen, B., Kirschenheiter, M. (2003), “Discretionary risk disclosure', The Accounting Review, Vol.78, No.2, pp. 449- 469.

Jorgensen, B., Kirschenheiter, M. (2007), "Voluntary disclosure of sensitivity' AAA 2009 Financial Accounting and Reporting Section (FARS) Paper, Available at SSRN: http://ssrn.com/abstract $=1270977$

Jorion, P. (2002), 'How informative are value at risk disclosure?', The Accounting Review, Vol.77, No. 4, pp. 911-931.

Landsman, W. and Maydew, R. (2002), "Has the information content of quarterly earnings announcements declined in the past three decades?" Journal of Accounting Research, Vol. 40, No. 3, pp. 797-808.

Lajili, K. and Zéghal, D. (2005), "A content analysis of risk management disclosures in Canadian annual reports", Canadian Journal of Administrative Sciences, Vol.11, No.2, pp. 125-142.

Lakhal, F. (2005), 'Voluntary earnings disclosures and corporate governance: evidence from France', Review of Accounting and Finance, Vol. 4, No. 3, pp. 64-85.

Li, J., Pike, R and Haniffa, R. (2008), "Intellectual capital disclosure and corporate governance structure in UK firms", Accounting and Business Research, Vol. 38, No. 2. pp. 137-159.

Linsley, P. and Shrives, P. (2000), "Risk management and reporting risk in the UK', Journal of Risk, Vol. 3, No.1, pp. 115-129.

Linsley, P. and Shrives, P. (2005), "Examining risk reporting in UK public companies", Journal of Risk Finance, Vol. 6, No. 4, pp. 292-305.

Linsley, P. and Shrives, P. (2006), "Risk reporting: a study of risk disclosures in the annual reports of UK companies", The British Accounting Review, Vol. 38, No. 1, pp. 387-404.

Linsmeier, T., Thornton, D., Venkatachalam, M. and Welker, M. (2002), "The effect of mandated market risk disclosure on trading volume sensitivity to interest rate, exchange rate, and commodity price movements", The Accounting Review, Vol. 77, No. 2,pp. 343-377.

Mangena, M. and Pike, R. (2005), "The effect of audit committee shareholding, financial expertise and size on interim financial disclosures", Accounting and Business Research, Vol. 35, No. 4, pp. 327-349. 
Marshall, A. and Weetman, P. (2002), "Information asymmetry in disclosure of foreign exchange risk management: can regulation be effective?", Journal of Economics and Business, Vol. 54, pp. 31-53.

Marshall, A. and Weetman, P. (2007), "Modelling transparency in disclosure: the case of foreign exchange risk management', Journal of Business Finance \& Accounting, Vol. 34, No. 5-6, pp. 705-739.

Morris, R. (1987), "Signaling, agency theory and accounting policy choice', Accounting and Business Research, Vol. 18, No. 69, pp. 47-56.

Rajab, B. and Handley-Schachler, M. (2009), "Corporate risk disclosure by UK firms: trends and determinants", World Review of Entrepreneurship, Management and Sustainable Development, Vol. 5, No. 3, 224-243.

Schadewitz, H and Blevins, D. (1998), "Major determinants of interim disclosures in an Emerging Market”, American Business Review, Vol. 16, No. 1, pp. 41-55.

Singh, M., Mathur, I. and Gleason, K. (2004), “Governance and performance implications of diversification strategies: evidence from large US firms', Financial Review, Vol. 39, pp. 489-526.

Smith Committee (2003), "Audit Committee Combined Code Guidance”, Financial Reporting Council, London, Available at:

http://www.ecgi.org/codes/documents/ac_report.pdf, Accessed on 9 May 2010.

Solomon, J, Solomon, A., Norton, S. and Josef, N. (2000), "A conceptual framework for corporate risk disclosure emerging from the agenda for corporate governance reforms', British Accounting Review, Vol. 32, No. 4, pp. 447-478.

Taylor, G., Tower, G. and Neilson, J. (2010), "Corporate communication of financial risk", Accounting and Finance, Vol. 50, pp. 417-446.

Wallace, R., Naser, K. and Mora, A. (1994), "The relationship between comprehensiveness of corporate annual reports and firm characteristics in Spain", Accounting \& Business Research, Vol. 25, No. 97, pp. 41-53.

Watson, A., Shrives, P. and Marston, C. (2002), "Voluntary disclosure of accounting ratios in the UK', British Accounting Review, Vol. 34, pp. 289-313.

Watts R. and Zimmerman L. (1983), "Agency problems, auditing and the theory of the firm: some evidence", Journal of Law \& Economics, Vol. 14, pp. 311-368.

Vandemele, S., Vergauwen, P.and Michiels, A. (2009), "Management risk reporting practices and their determinants: a study of Belgian listed firms", Available at:

https://uhdspace.uhasselt.be/dspace/bitstream/1942/9392/2/CorporateriskB.pdf (Accessed 15 June 2010). 
Table (1) firm characteristics and their expected relationship with CRD disclosure based on prior studies

\begin{tabular}{|c|c|c|}
\hline Characteristics & $\begin{array}{l}\text { Association sign based } \\
\text { on prior research }\end{array}$ & Examples for prior studies \\
\hline Activity type & + & $\begin{array}{l}\text { Cooke (1992); Mangena and Pike } \\
(2005)\end{array}$ \\
\hline Firm size & + & $\begin{array}{l}\text { Hossain et al. (1995); Watson et al. } \\
\text { (2002); }\end{array}$ \\
\hline Profitability & $+/-$ & $\begin{array}{l}\text { Wallace et al. (1994); Hussainey and Al- } \\
\text { Najjar (2011) }\end{array}$ \\
\hline Gearing & $+/-$ & Ahmed and Courtis (1999) \\
\hline Liquidity & $+/-$ & $\begin{array}{l}\text { Wallace et al. (1994); Watson et al. } \\
\text { (2002); Mangena and Pike, (2005) }\end{array}$ \\
\hline Cross listing & + & $\begin{array}{l}\text { Cooke (1992); Wallace et al. (1994); } \\
\text { Mangena and Pike (2005); Aly et al., } \\
(2010)\end{array}$ \\
\hline
\end{tabular}

Table (2) CG mechanisms and their expected relationship with CRD disclosure based on prior studies 


\begin{tabular}{|c|c|c|}
\hline CG mechanisms & $\begin{array}{l}\text { Association sign based on } \\
\text { prior research }\end{array}$ & Examples for prior studies \\
\hline $\begin{array}{l}\text { Institutional } \\
\text { ownership }\end{array}$ & $+/-$ & $\begin{array}{l}\text { Eng and Mak (2003); Mangena and Pike } \\
\text { (2005) }\end{array}$ \\
\hline Duality role & $+/-$ & $\begin{array}{l}\text { Forker (1992); Haniffa and Cooke (2002); Ho } \\
\text { and Wong (2001) }\end{array}$ \\
\hline Size of the board & $+/-$ & $\begin{array}{l}\text { Singh et al. (2004); Lakhal (2005); Abdel- } \\
\text { Fattah et al. (2007) }\end{array}$ \\
\hline $\begin{array}{l}\text { Board } \\
\text { composition }\end{array}$ & $+/-$ & $\begin{array}{l}\text { Ho and Wong (2001); Haniffa and Cooke } \\
\text { (2002); Hussainey and Al-Najjar (2011) }\end{array}$ \\
\hline $\begin{array}{l}\text { Size of audit } \\
\text { committee }\end{array}$ & + & $\begin{array}{l}\text { Felo et al. (2003); Mangena and Pike (2005); } \\
\text { Tauringana and Mangena ( 2009) }\end{array}$ \\
\hline
\end{tabular}

Table 3: Definition and measurement of independent variables 


\begin{tabular}{|c|c|c|c|}
\hline Label & Definition & Measurement & Source \\
\hline Industry & Activity type & $\begin{array}{l}1 \text { if the company activity is industrial, } 0 \text { if the } \\
\text { company is a service }\end{array}$ & FAME \\
\hline Size & Firm size & Natural logarithm of total assets as at the end of & FAME \\
\hline Prof & profitability & [Net profit after tax / Shareholders funds] $10 \times 0$ & FAME \\
\hline Gear & Gearing & $\begin{array}{l}{[(\text { Short term loans and overdrafts +long term }} \\
\text { liabilities }) / \text { Shareholders funds }] \times 100 \%\end{array}$ & FAME \\
\hline Liq & Liquidity & Current assets / Current liabilities & FAME \\
\hline Croslist & Cross listing & $\begin{array}{l}1 \text { if the company listed in US market, } 0 \text { if } \\
\text { otherwise }\end{array}$ & $\begin{array}{l}\text { SEC } \\
\text { Website }\end{array}$ \\
\hline Inst & $\begin{array}{l}\text { Institutional } \\
\text { ownership }\end{array}$ & $\begin{array}{l}\text { Percentage of equity ownership by } \\
\text { institutions. }\end{array}$ & Datastream \\
\hline Dual & Role duality & 1 if CEO is the chairman and 0 if otherwise. & $\begin{array}{l}\text { Annual } \\
\text { reports }\end{array}$ \\
\hline Bsize & Size of the board & $\begin{array}{l}\text { The total number of the members on the } \\
\text { board }\end{array}$ & $\begin{array}{l}\text { Annual } \\
\text { reports }\end{array}$ \\
\hline Nonexc & $\begin{array}{l}\text { Board } \\
\text { composition }\end{array}$ & $\begin{array}{l}\text { [Number of non-executive directors/ total } \\
\text { number of directors on the board] } \times 100 \% \text {. }\end{array}$ & $\begin{array}{l}\text { Annual } \\
\text { reports }\end{array}$ \\
\hline ACsize & $\begin{array}{l}\text { Size of audit } \\
\text { committee }\end{array}$ & Number of directors in the audit committee. & $\begin{array}{l}\text { Annual } \\
\text { reports }\end{array}$ \\
\hline
\end{tabular}

Table: 4: Descriptive statistics 
Panel A: Descriptive Statistics of Continuous variables $(\mathrm{N}=72)$

\begin{tabular}{|c|c|c|c|c|}
\hline Variable & Mean & Minimum & Median & Maximum \\
\hline Size & 18136.2 & 844.5 & 7933.5 & 170000 \\
\hline Liq & 1.39 & 0.32 & 1.17 & 7.48 \\
\hline Gear & 167.9 & 0.1 & 93.7 & 1189.0 \\
\hline Prof & 22.93 & -94.37 & 19.89 & 273.64 \\
\hline Inst & 70.94 & 17.38 & 74.58 & 99.60 \\
\hline Bsize & 10.74 & 6.00 & 11.00 & 17.00 \\
\hline Nonexc & 68.14 & 0.00 & 71.00 & 92.00 \\
\hline Acsize & 4.10 & 2.00 & 4.00 & 7.00 \\
\hline Total & 28.43 & 5.00 & 21.50 & 110.00 \\
\hline
\end{tabular}

Panel B: Descriptive Statistics of Dummy variables $(\mathrm{N}=72)$

\begin{tabular}{|c|c|c|c|}
\hline Variable & Dummy & $\mathrm{N}$ & $\%$ \\
\hline Industry & 1 & 50 & 69.44 \\
& 0 & 22 & 30.56 \\
\hline Croslist & 1 & 19 & 26.39 \\
& 0 & 53 & 73.61 \\
\hline Dual & 1 & 4 & 5.56 \\
& 0 & 68 & 94.44 \\
\hline
\end{tabular}


Table 5: Determinants of total CRD in UK interim reports

\begin{tabular}{|c|c|c|c|c|}
\hline & odel & Coefficient Estimate & T-Statistic & p-value \\
\hline 1 & (Constant) & $-55.915^{\star \star}$ & -2.023 & .048 \\
\hline & INDUSTRY & $11.870^{\star \star}$ & 2.300 & .025 \\
\hline & Size & $17.172^{\star * \star}$ & 3.123 & .003 \\
\hline & Liq & 2.544 & 1.188 & .240 \\
\hline & Gear & -.007 & -.572 & .569 \\
\hline & Prof & .027 & .470 & .640 \\
\hline & Croslist & -8.719 & -1.472 & .146 \\
\hline & Inst & 145 & 1.096 & 277 \\
\hline & Dual & 9.754 & 957 & .343 \\
\hline & Bsize & .009 & .008 & .994 \\
\hline & Nonexc & -.012 & -.068 & .946 \\
\hline & Acsize & .106 & .046 & .964 \\
\hline & R-Square & \multicolumn{3}{|c|}{0.261} \\
\hline & F-test & \multicolumn{3}{|c|}{$1.189^{*}(0.059)$} \\
\hline
\end{tabular}

Variables are defined in Table 5. *** indicates significance at the 0.01 level; ** indicates significance at the 0.05 level, * indicates significance at the 0.10 level. 